\title{
Antibacterial activity of the ethanolic extract \\ of some plant leaves on aerobic and anaerobic \\ pathogens
}

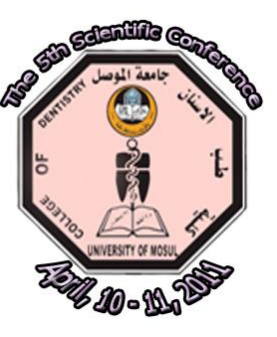

\begin{abstract}
Aims: To evaluate the antibacterial effect of ethanolic extracts of three medicinal plants (Camellia sinensis,green and black tea, and Ziziphus spp) on different aerobic and anaerobic bacteria. Material and Methods: The leaves of black tea, green tea, and ziziphus from local markets were collected and extracted in ethanol, the antibacterial activity of 50,5 , and $0.5 \%$ of the ethanol extracts against Escherechia coli, Staphylococcus aureus, Actinobacilus actinomycetemcomitans, viridians streptococci and black pigmenting bacteria were investigated using paper disk diffusion technique. Results: The results obtained showed that ethanolic extract exhibited antibacterial activities against Escherechia coli, Staphylococcus aureus, Actinobacilus actinomycetemcomitans, viridians streptococci and black pigmenting bacteria. The extracts produced inhibition zones ranging from $2-32 \mathrm{~mm}$ against the test bacteria compared with chlorhexidin $(12-15 \mathrm{~mm})$. Conclusions: The ethanolic extracts of the examined plants were effective antibacterial agents against the aerobic and anaerobic bacteria especially the periodontopathogens so we suggest to use them in treatment and prevention of gingivitis and periodontitis.
\end{abstract}

Asst Prof Ghada Y Abdul-

$\operatorname{Rahman}(B S c, M S c, P h D)$

Department of Dental Basic Sciences, Dentistry College, Mosul University

Key Words: Antibacterial, green tea, black tea, ziziphus.

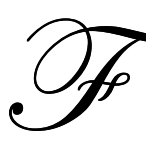

\section{INTRODUCTION}

inding healing powers in plants is an ancient idea. People on all continents have long applied poultices and imbibed infusions of hundreds, if not thousands, of indigenous plants, dating back to prehistory. Currently, of the one-quarter to one-half of all pharma-ceuticals dispensed in the United States having higher-plant origins, very few are intended for use as antimicrobials, since we have relied on bacterial and fungal sources for these activities.

Clinical microbiologists have two reasons to be interested in the topic of antimicrobial plant extracts. First, it is very likely that these phyto-chemicals will find their way into the arsenal of antimicrobial drugs prescribed by physicians; several are already being tested in humans, Second, the public is becoming increasingly aware of problems with the over prescription and misuse of traditional antibiotics. In addition, many people are interested in having more autonomy over their medical care. A multitude of plant compounds (often of unreliable purity) is readily available over-the-counter from herbal suppliers and natural-food stores, and self-education with these substances is commonplace ${ }^{(1)}$ 
The use of medicinal plants as a source for relief from illness can be traced back over five millennia to written documents of the early civilization in China, India and the Near east, but it is doubtless an art as old as mankind. ${ }^{(2,3)}$.Both green and black tea come from the leaves of the plant Camellia sinensis, however the processing that the leaves undergo to make the final tea is different. The leaves for black tea are fully oxidized while those for green teas are lightly steamed before being dried. Black and green teas both contain similar amount of flavonoids however they differ in their chemical structure. Green teas contain more of the simple flavonoids called catechins, while the oxidization that the leaves undergo to make black tea converts these simple flavonoids to the more complex varieties called theaflavins and thearubigins. Black teas mostly come from plantations in Africa, India, Sri Lanka and Indonesia while green teas come from countries in the Far East such as China and Japan. ${ }^{(4,5)}$

Green tea ( Camellia sinensis) is a rich source of polyphenols, particularly flavonoids that have beneficial effects in the treatment of certain forms of cancer, arthritis, and cardiovascular disorders ${ }^{(6,7)}$

Ziziphus spp. ( Rhamnaceae) are commonly used in folklore medicine for the curing of various diseases .They are wide spread in the Mediterranean Region ,Africa, Australia, and tropical

America. Ziziphus (pronounced /'ZIZifəs/) ${ }^{(8-10)}$ is a genus of about 40 species of spiny shrubs and small trees in the buckthorn family Rhamnaceae, distributed in the warm-temperate and subtropical regions throughout the world. The leaves are alternate, entire, with three prominent basal veins, and 2-7 cm (0.79-2.8 in) long; some species are deciduous, others evergreen. The flowers are small, inconspicuous yellow-green. The fruit is an edible drupe, yellow-brown, red, or black, globose or oblong, $1-5 \mathrm{~cm}(0.39-2.0$ in) long, often very sweet and sugary, reminiscent of a date in texture and flavour ${ }^{(11)}$

The best known species is Z. zizyphus (Jujube). Other species include Z. spina-christi from southwestern Asia, Z. lotus from the Mediterranean region, and Ber (Ziziphus mauritiana), which is found from western Africa to India. Ziziphus joazeiro grows in the Caatinga of Brazil ,belongs to the family Rhamnaceae. The fruits used anodyne and tonic.They form one of the ingredients of shanda, a medicine used in chest troubles. Kernels sedative, used as soporific and to stop vomiting; employed as an antidote to aconite-poisoning and in abdominal pains. Seeds are given in diarrhea. ${ }^{(12)}$

\section{Plant collection}

\section{MATERIALS AND METHODS}

The air-dried leaves of black and green tea (Camellia sinensis)and ziziphus were collected from the local market in the dry form. The leaves were cut into pieces and grinded into powdery form using a sterile electric grinder.

\section{Ethanol extraction}

The ethanol extractions of the leaves were carried out using the method as described by Harbone (1994). $25 \mathrm{~g}$ of the grinded leaves were extracted using $250 \mathrm{ml}$ of $95 \%$ ethanol, concentrated by evaporation using water bath at $100^{\circ} \mathrm{C}$.

\section{Test organisms}

The strains used in this work were Escherechia coli, Staphylococcus aureus, Actinobacilus actinomycetemcomitans, viridians streptococci and black pigmenting bacteria obtained from clinical and oral specimens from patients attending the dental hospital at college of 
dentistry ,Mosul University,the bacteria were maintained by weekly transfer in tryptic soy broth (TSB) and thioglycolate broth,cells were grown at $37^{\circ} \mathrm{C}$ for $48 \mathrm{~h}$ and cultures were kept at $4^{\circ} \mathrm{C}$.

\section{Antibacterial susceptibility testing}

The antibacterial tests of the leaf extracts were tested on the test bacteria using the paper disk diffusion inhibition test, sterile paper discs were soaked in the leaf extract for $2 \mathrm{~h}$. $0.2 \mathrm{ml}$ of a 24 $\mathrm{h}$ broth culture of the bacteria species was spread on the surface of gelled sterile Mueller-Hinton agar plates. The paper discs containing the extracts were placed at different areas on the surface of each plate. The plates were incubated at $37^{\circ} \mathrm{C}$ for $24 \mathrm{~h}$. Antibacterial activity of the extract against the test bacteria was indicated by growth -free "zone of inhibition" near the respective disc.

\section{RESULLTS and Discussion}

The ethanolic extract of the leaf of $C$. sinensis and Ziziphus spp. Showed various levels of antibacterial activity when tested by diffusion method, as shown in figures 1-3.

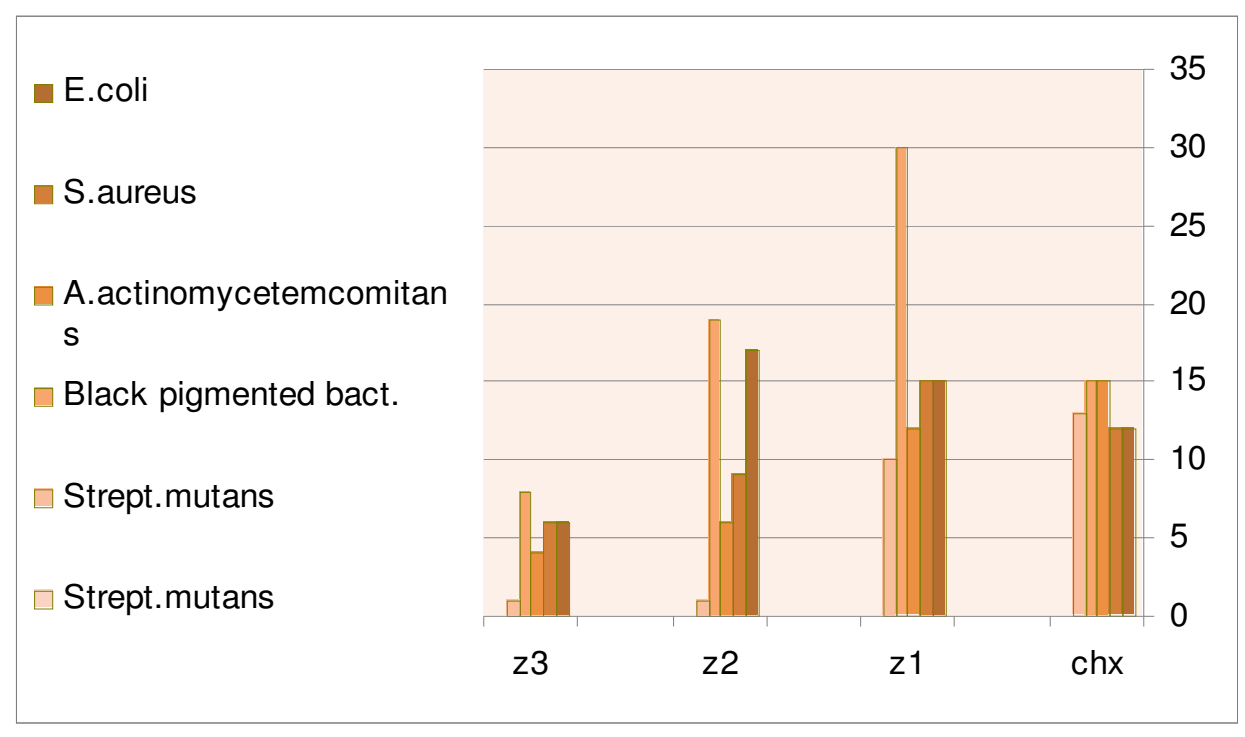

Figure (1):Effect of ziziphus leaves extract on different bacteria

Ziziphus leaves extract show it's best antibacterial effect against Stret. Mutans at the $1^{\text {st }}$ concentration $(50 \%)$ compared to chlorhexidine.

All parts of the plant are used by the local Arab people to help maintain a healthy lifestyle. The plant has also been used for its soothing properties In Saudi Arabia it is used for the treatment of ulcers, wounds, eye diseases and bronchitis. The Bedouin use it for the treatment of wounds, skin diseases and as an anti-inflammatory. They also use it as a febrifuge and diuretic. Methyl esters isolated from leaves included methyl palmitate, methyl stearate and methyl myristate. betaSitosterol, oleanolic acid and maslinic acid were the main aglycones of the glycosides present in leaves. Sugars present in leaves included lactose, glucose, galactose, arabinose, xylose and rhamnose. The plant also contains four saponin glycoside.

The Arabs call it Nabka [Grieve]. Sudan: Nabag, Nabak, Cidir, Christ's thorn (in folklore, the plant is said to be the source of the crown of thorns placed on the Saviour's head [Levy]). Nigeria (Hausa): Kurna. In English it is known as Dom, Jerusalem-thorn or Christ-thorn, In French it is called Paliure, épine du Christ, porte-chapeau, capelets, argolou and arnaves ${ }^{(13)}$ 
B. Mahesh and Satish (2008) found that leaf extract of Z. mauritiana showed highest activity against E. coli $(18 \mathrm{~mm})$ and lowest activity were observed in $S$. aureus, P. fluorescens and $B$. subtilis around $(15 \mathrm{~mm}$ )zone of inhibition. Bark extract of this plant showed significant activity against $S$. aureus followed by $E$. coli and the minimum activity were observed in B. subtilis and P. fluorescens $^{\text {(12). }}$

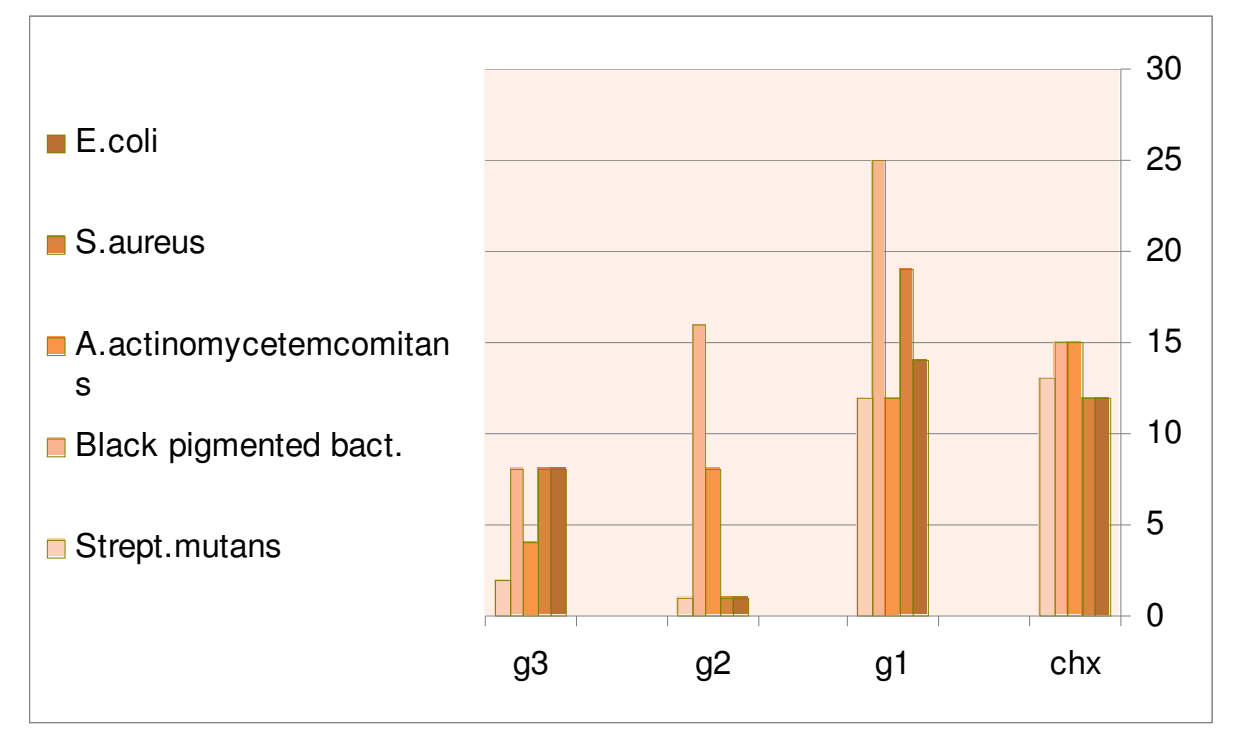

Figure(2):Effect of green tea extract on different bacteria

The green tea leaves show good antibacterial activity against black pigmenting bacteria ,Staph.aureus compared to chlorhexidine.

Previous studies have reported that green tea polyphenols (TPP), collectively termed catechins including epicatechin (EC), epicatechin gallate (ECG), epigallocatechin (EGC), and epigallocatechin gallate (EGCG), have bactericidal activity against various Gram-positive and Gram-negative bacteria . Recently, EGCG was reported to act synergistically with various $\beta$ lactam antibiotics against MRSA

Toda et al. (1989b) reported that daily consumption of green tea can kill gram positive $S$. aureus and other harmful bacteria. Also it has been reported that the green tea contains catechin and polyphenols. These compounds have been found to possess antibacterial and antiviral action as well as anticarcinogenic and antimutagenic properties. This suggests that these compounds could be responsible for the inhibition of pathogens. 


\section{Abdul-Rahman GhY}

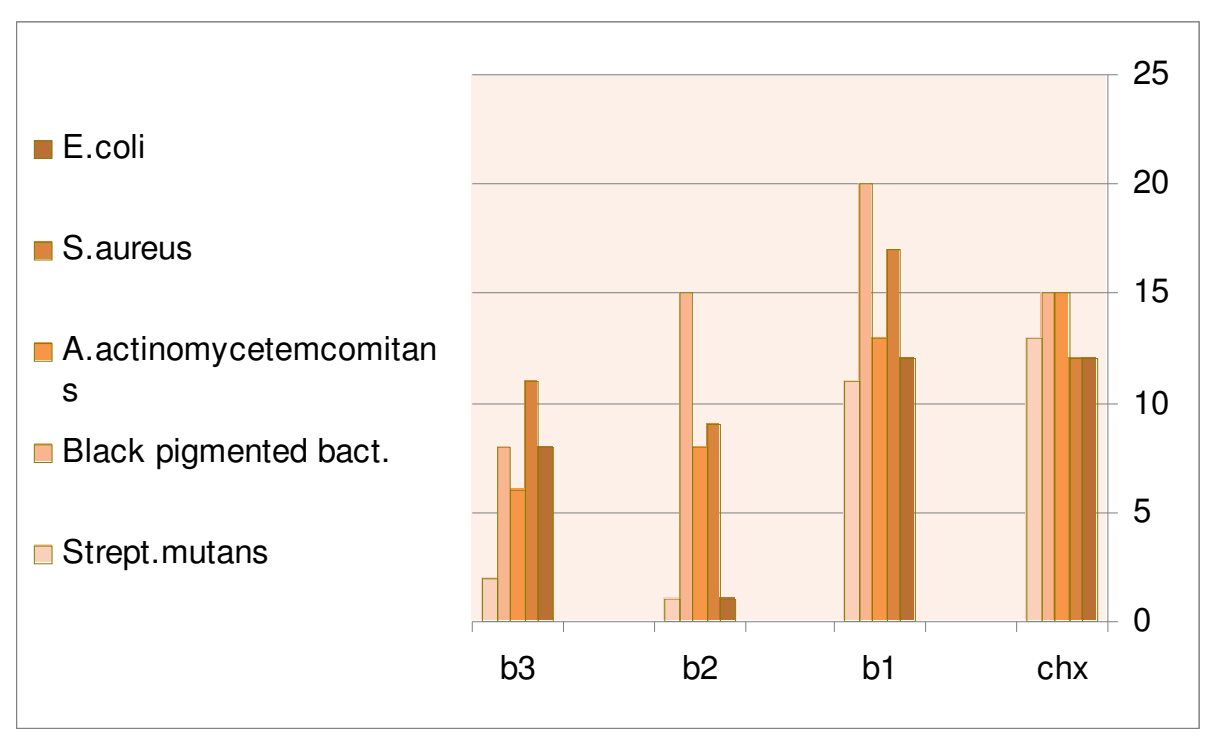

Figure(3):Effect of black tea extract on different bacteria

The best effect of black tea found against black pigmenting bacteria and Staph.aureus .

Tea is an infusion of flavorful leaves that has been consumed for centuries as a beverage and is valued for it's medicinal properties.The phytochemicals screening of tea revealed the prescence of alkaloids ,saponins, tannins, catechins and polyphenols ${ }^{.(14)}$

\section{REFERENCES}

1. (MARJORIE MURPHY COWAN*,Plant Products as Antimicrobial Agents, Cinical Microbiology Reviews, Vol.12, No.4,Oct. 1999; p: 564-582 .

2. Thomson, W.A.R., Medicines from the Earth Maiden head, 1978.United Kingdom. McGraw-Hill Book co

3. Stockwell, C.. Nature's pharmacy.1988. LondonUnited Kingdom. Century Hutchinson Ltd.

4. Sarkar A, et al . Black tea is a powerful chemopreventor of reactive oxygen and nitrogen species: comparison with its individual catechin constituents in green tea. Biochem. Biophyss. Res. Commun; 2001; 284 (1): 173-178

5. Benzie IF, et al Consumption of green tea causes rapid increase in plasma antioxidant power in humans. Nutr Cancer; 1999; 34(1):83-7

6. Pe'rola D. B. Ribaldo,4 Denise S. Souza, Subrata K. Biswas, Karen Block, Jacqueline M. Lopes de Faria,and Jose' B. Lopes de Faria, Green tea (Camellia sinensis) Attenuates Nephropathy by Downregulating Nox4NADPH Oxidase in Diabetic Spontaneously Hypertensive Rats, The Journal of Nutrition, 2009 American Society for Nutrition. First published online December 3, 2008; doi:10.3945/jn.108.095018.

7. Higdon JV, Frei B. Tea catechins and polyphenols: health effects, metabolism, and antioxidant functions. Crit Rev Food Sci Nutr. 2003; 43:89-143.

8. Ziziphus Mill.". TROPICOS. Missouri Botanical Database. http://www.tropicos.org/Name/40028635. Retrieved 2009-10-01.

9. "Ziziphus Mill.". Germplasm Resources Information Network. United States Department of Agriculture. 2004-0210. http://www.ars-grin.gov/cgi-bin/npgs/html/genus.pl?13055. Retrieved 2009-10-01.

10. Sunset Western Garden Book 1995; 606-607 .

11. S. Azam-Ali,E. Bonkoungou,C. Bowe,C. deKock,A. Godara,J.T. Williams, ( Fruits for the Future) .2(Revised edition)Ber and other jujubes. First published in 2001 by International Centre for Under utilised Crops, University of Southampton, Southampton, SO17 1BJ, UK)

12. B. Mahesh and 2S. Satish .Antimicrobial Activity of Some Important Medicinal Plant Against Plant and Human Pathogens. World Journal of Agricultural Sciences 4 (S): 839-843, 2008; ISSN 1817-3047

13. Anthony C. Dweck FLS FRSC FRSH .A review of Zizyphus spina-christi , July 2005

14. Mbata,T.I.Preliminary studies of the antibacterial activities of Kenyan and Nigerian tea.African J. of Biotech.Vol.6(3),pp: 278-279,5 feb 2007. 